УДК 338.487:005.332.4

\title{
THE DETERMINERS OF URBAN TOURIST PRODUCT'S COMPETITIVENESS
}

\author{
A. Panasiuk \\ University of Szczecin \\ Szczecin, Poland
}

\begin{abstract}
Tendencies on the tourism market, especially elements of the market surroundings like globalization, liberalization, crisis in the economy, changes in purchase preferences, force entities offering tourist products to search the new solutions that allow to gain a competitive advantage.

Tourist product is a multi- dimensional category and comprises operation of tourist entities offering services as well as tourist areas that create complex offers. Therefore tourist product is determined by the operation of many entities that manage the elements of tourism product's structure.
\end{abstract}

Keywords: competetiveness, tourism product

Contemporary trends in tourism market, especially globalization, liberalization, changes in customer tastes force all tourism organizations to seek new solutions to secure a competitive advantage.

Tourism product is a multidimensional notion. It covers product of various organizations: those that offer services, as well tourism product of an area which is a composite of various elements. Hence, the competiveness of total tourism product (i.e. area product) is determined by actions of various organizations that manage different part of its product, i.e.:

- Tourism branch,

- Public sector,

- Tourism organizations.

All those actions are directly aimed at fulfilling needs of tourists in the destination and are concentrated at the preserving tourism attractions, maintaining tourism infrastructure and improving tourism offers in a destination which covers also actions aimed at creating tourism image (of a city).

The aim of the paper is to present a key determinants of competiveness of tourism product at the city level. The subject is connected with actions of all organizations responsible of creating a total tourism product and possibilities of improving its structure and quality, which is of vital importance to the competiveness of city tourism destinations.

\section{City tourism product}

The very first step to further considerations is to interpret the essence of tourism product. According to marketing point of view, product is everything which can be traded on the market. Product may be defined as an offer and can have a form of either commodity or service or even an idea. In the narrow view tourism product can be understood as everything a tourist may purchase (e.g. transportation, hospitality, catering services). This notion corresponds to the marketing view of product, which is used in the marketing 
of both commodities (i.e. tangible goods) and services (non-tangible goods). The wide view of tourism product is directly connected with supply side of tourism and is aimed at composition of tourism activity during tourism journey and in the tourism destination. It includes also tourism attractions and tourism services which are used by tourist [8] From a different perspective tourism product is defined as all commodities and services created and purchased in connection with the journey out of a usual living place. It covers also goods that are purchased before or after a journey, if those goods are connected with the aim of the journey [13]. The main problem of tourism product in a wide view, is to indicate all factors that determine its structure:

- Tourism attractions (both natural-based and cultural-based)

- Tourism infrastructure and tourism attractions,

- Transport accessibility

- Image of destination,

- The price level.

Tourism product is a multidimensional category. The basic typology of tourism product distinguishes between two categories:

- Narrow view - the product of tourism organizations,

- Wide view - total tourism product.

According to the concept of W. Freyer [6] one can distinguish between three categories of tourism product:

- Country

- Region (in administrative borders)

- Commune, city.

This typology indicates sharing of competences in frames of maintaining total tourism product, starting from national tourism administrations (NTA) and public bodies at regional and local level.

The basic area that is connected with creating total tourism product necessarily involves the action of local public bodies. They may act solely on the tourism market or in cooperation with tourism companies, creating together a total tourism product. Public bodies undertake a various actions connected mainly with tourism infrastructure and tourism promotion. This leads to the possibility of creating a city tourism brand.

From the tourist's point of view, it is necessary to indicate an image of a tourist destination, its experiences connected with journey and stay in a destination and impressions after a journey [1]. This notions are very subjective, however they unambiguously determine the tourism product's evaluation and represented patterns of its purchase in the future.

In this place it is vital to indicate all elements that comprise a tourism product in a wide view. It is to underline that those elements and actions directed to the market are very wide. Among all tradable on the market goods one can distinguish:

- Commodities and services that are directly influenced by tourism (transportation, hospitality, tourism guides)

- Commodities and services, which purchase is influenced by tourism, but they represent a sort of consumption substitution (clothes, catering)

- Commodities and services, which meets the same needs both in population of tourists and local community (banking, insurance, medical services, local infrastructure). 
So the total tourism product is comprised of:

a) Tourism goods

- Basic goods - tourism attractions, both natural- and culture-based,

- Complementary goods - material commodities which constitute a base for offering tourism services (transportation system, hotels, restaurants, ancillary services)

a) Tourism services

- Basic - services that facilitate arrival, stay and departure from tourist destination (those services are based on the complementary goods),

- Complementary - services offered in connection with tourism attractions (tourist guides' services, recreation, culture, sport devices hire etc.)

Creating a total tourism product is aimed at tourism flow. The concept of city tourism product derives from historical, cultural and geographical conditions. Structure of city tourism product is additionally conditioned by natural factors [9].

City tourism product is composed of:

a) Primarily elements

- Cultural-based attractions (theaters, galleries, museums),

- Historic monuments,

- Sport-based attractions,

- Leisure,

- Natural-based attractions, (parks, botanical gardens etc.)

- Socio-cultural factors (language, ambience, habits, folklore, citizens attitude towards tourists)

- events

b) Secondary elements:

- hospitality services,

- catering,

- transportation accessibility

- tourist information

- retails network [7].

City tourism product is determined spatially. For this reason it is not a pure sum of city tourism products that are offered in the city area, but it is also determined by natural-based tourist attractions (characteristic to the region), and a transportation system (internal and external).

Creating a total tourism product of a city destination requires, apart from mentioned elements, also institutional actions. The main condition to build a total tourism product of a destination, is not only a presence at the area of elements comprising a total tourism product of city destination (attractions, infrastructure, services), but also it is vital to create a cooperation practices. Moreover it is necessary to perform actions that support tourism product and its elements (preserving natural attractions, investments in tourism infrastructure, development of tourism services).

Actions undertaken separately by tourism companies, public bodies and tourism organizations determine not only a presence of local tourism product but also a local tourism economy [2].

Summarizing considerations above, it is necessary to indicate the array of reasons of stay 
in city tourism, which also determines actions toward building city tourism product. Main forms of city tourism are: cultural tourism, leisure tourism, business tourism, visiting friends and relatives and others (religious, transit, shopping, occasional job).

\section{Competitiveness in tourism economy}

Competitiveness is an economic category, which became one of the most popular issue during the last decade, both in theoretical and in empirical research. Similarly to the term competition, competitiveness is a term connected with market relations.

Competition is a process, which enables actors of the market to secure their own interest and attempt to deliver more attractive products than their competitors in terms of price, quality or other product characteristics [12]. In other view, competition is a struggle between companies to get benefits obtained from selling commodities and services and a struggle for delivery market and for labor market [4]. Competition processes can be observed both among sellers and among buyers. Competitive market would be a market, where neither buyers nor sellers may have a competitive advantage, so the market has no traits of monopoly. Competitive market occurs in a situation, where supply side of a market uses in an integrated manner following instruments:

- basic products - creating an offer,

- additional products - improving basic offer,

- price - discrimination and apply conditions,

- distribution - efficient reaching of customers and shaping delivery system,

- communication - information policy [11].

Competitiveness may be understood in two dimensions:

a) attributive (result), as a selection of traits that decide of being competitive,

b) process, as a procedure which must be accomplished to obtain desired traits, to become competitive [3].

Competitiveness may be connected with:

a) different levels of economic system, i.e. in global, macro, mezzo and micro dimension,

b) spatial determined at the country, regional and local level.

Most typical research in the area of competitiveness is connected with the first group, i.e. the analysis of competitiveness of national economies, sectors and branches. Spatial aspect of competitiveness is more and more often emphasized in the competitiveness research. The presence of communes, counties, cities and regions is analyzed.

The above mentioned typology of competitiveness relates to the topic of the article. From one side there are connected with sector approach, i.e. tourism (mezoeconomic level), and from the other side spatial connection - local public body, i.e. a city.

Creating competitiveness, according to the concept of area marketing, becomes one of the fundamental responsibilities of public bodies in relation to investors, tourists and local community.

Influencing competitiveness of a local (city) tourism economy is connected with the usage of similar instruments, as in the case of companies. The most fundamental attributes of competitiveness are price and quality of tourism product.

Factors determining competitiveness of city tourism product

The full analysis of competitiveness of a total (city) tourism product in a complex 
view, is very difficult. The main culprit is the wide range of elements comprising total tourism product and a difficulty of assessing those elements at a time. Considering tourists' individual purchasing decisions (consumers of that product) and usage of various selections of elements comprising consumed product, the assessment of total tourism product of a city destination by different tourist would result in an assessment of different selections of city product elements (leisure, shopping, visiting friends and relatives). The greatest tourist potential of a city, the more factors differentiate its structure and assessment of its competitiveness.

In order to assess the levels of competitiveness of tourism products, it is possible to use some available measures, which enable its fractional and general assessment. The most synthetic measure of tourism supply, so also a total tourism product is tourism attractiveness, which bases on the quantitative data results in qualitative characteristic of an area. Moreover it enables creating a rating of communes, counties and regions in order to present its competitive position.

Tourism attractiveness may be interpreted as a sum of subjective and objective assessments of selected elements of tourist supply in borders of given prices and incomes [13]. Tourism attractiveness is a composite of tourism supply elements, i.e.:

- tourism attractions,

- tourism infrastructure (hotels, restaurants etc.)

- transportation accessibility

- natural environment, its present condition and actions aimed at its preservation [10].

Using appropriate methods and a set of fractional measures it is possible to construct a general index, which enables to make comparisons in time and space (between different tourist destinations).

The assessment of tourist attractions (cultural- and natural-based) should include their number, differentiation, importance, preservation and accessibility to tourists.

In relation to infrastructure the assessment should include: size, differentiation from the tourists preferences and income point of view, quality level in hospitality and catering.

Transportation accessibility is connected with the possibility of reaching a city with different mean of transport. It includes moreover the connection between internal and external transportation system, the quality of internal transportation system and its product for tourist.

The assessment of environmental preservation includes the level of its degradation and pollution. It appears that for a city destinations this problem has a secondary importance. Still, the quality of water, cleanliness of streets, system of rubbish delivery to dump have a deciding importance to the decision whether to visit a given city.

Extending the area of competitiveness of total tourist product of city destinations, it is possible to suggest a list of attributes classified in four groups:

a) typical fractional measures, covering tourism attractiveness:

- tourism attractiveness,

- tourism infrastructure,

- transport accessibility,

- preservation of natural environment.

b) Other tourism resources and marketing actions, 
- Other tourism attractions (cultural, sport, recreation, leisure),

- System of local tourism economy management (e.g. city tourism information system),

- The qualitative and quantitative level of labor in tourism industry and tourism organizations and departments in public bodies,

- Promotional instruments, its range and budget,

- Creating an image of a city

c) Institutional actions,

- Erection and operation of city tourism organization,

- Other forms of cooperation between actors in tourism industry,

- Cooperation between schools and universities and tourism organizations,

- Erection and operation of Convention Bureau (cooperation in business tourism product)

d) Structure and improvement of tourism product

- Structure of tourism offer (width and depth of its range)

- Special facilitation for tourists (e.g. city card)

- Local taxes

- Creating relation price-quality.

The presented scope of factors determining the level of competitiveness of city tourism product is not directly measureable. Still, it is possible to compare its level through a system of grading scales or satisfaction level analysis among tourists. This would result in a complex system of assessing a competitiveness level of city tourism product. The whole range of fractional results and an attempt of synthetic qualitative index enable to determine the level of competitiveness of tourism city product, which may influence the size and structure of incoming tourism.

\section{The measurement of competitiveness of city tourism product}

The range of tourism product competitiveness approach covers following issues: resources, institutions, marketing. In relation to the topic of this paper, it covers the operation of city tourism destinations in a complex view and, complementally, operation of organizations producing tourist services. In order to assess the level of competitiveness of city tourism destination it is possible to conduct, as an idea, comparative study on example of selected city destinations. Table 1 presents a selection of elements that determine the level of competitiveness of city tourism destinations. In the system it is possible to use fractional indices which should be ranged (range 1-5) and converted in an aggregated index (e.g. in points 1-10).

The assessment of competitiveness of city tourism product covers the measuring of selected determinants that influence competitiveness of the product and, moreover, assessment of operation of fundamental tourism companies in a city destination (tourism and internal transportation, hospitality, catering, tourist information, tourist guides, system of customer service in tourist attractions).

Conducting a measurement of selected parameters presented in table 1, with considering its range, gives a basis to calculate a general value and determine a position of city destination in relation to others in aspect of competitiveness of tourism product. Preparing a practical measurement is a tedious and time-consuming task. It requires a research with 
division to different categories of city tourism destinations, e.g. size, position, structure of tourism flow, seasonality, position in the tourism market (internal and international).

Table 1 Comparative research of competitiveness of city tourism destinations

\begin{tabular}{|c|c|c|c|c|c|}
\hline \multicolumn{4}{|c|}{ Points (1-10) } & \multirow[b]{2}{*}{ city $\mathrm{C}$} & \multirow[b]{2}{*}{ city D } \\
\hline & Range (1-5) & city $\mathbf{A}$ & city B & & \\
\hline \multicolumn{6}{|c|}{ Measures of tourism attractivness } \\
\hline \multicolumn{6}{|l|}{ Tourism attractions } \\
\hline \multicolumn{6}{|l|}{ Tourism infrastructure } \\
\hline \multicolumn{6}{|l|}{ Transport accessibility } \\
\hline \multirow{2}{*}{\multicolumn{6}{|c|}{\begin{tabular}{|l|}
$\begin{array}{l}\text { Preservation of natural } \\
\text { environment }\end{array}$ \\
\end{tabular}}} \\
\hline & & & & & \\
\hline \multicolumn{6}{|l|}{ Other tourism attractions } \\
\hline \multicolumn{6}{|l|}{\begin{tabular}{|l|}
$\begin{array}{l}\text { System of local tourism } \\
\text { economy management }\end{array}$ \\
\end{tabular}} \\
\hline \multicolumn{6}{|l|}{ Labor in tourism } \\
\hline \multicolumn{6}{|l|}{ Tourism promotion } \\
\hline Image creation & & & & & \\
\hline \multicolumn{6}{|c|}{ Assessment of institutional actions } \\
\hline \multicolumn{6}{|l|}{ City tourism organization } \\
\hline \multicolumn{6}{|l|}{ Cooperation with industry } \\
\hline \multicolumn{6}{|l|}{$\begin{array}{l}\text { Cooperation with other } \\
\text { institutions }\end{array}$} \\
\hline \multicolumn{6}{|l|}{$\begin{array}{l}\text { Cooperation with schools } \\
\text { and universities }\end{array}$} \\
\hline Convention Bureau & & & & & \\
\hline
\end{tabular}

\begin{tabular}{|l|l|l|l|l|l|}
\hline \multicolumn{5}{|c|}{ Structure and improvement of tourism product } \\
\hline Tourism offer & & & & \\
\hline Facilitation for tourists & & & & & \\
\hline Local taxes & & & & & \\
\hline Relation price-quality & & & & & \\
\hline \multicolumn{5}{|c|}{ Operation of direct tourism economy } & \\
\hline $\begin{array}{l}\text { Tourist transport and city } \\
\text { transport }\end{array}$ & & & & & \\
\hline Hotels & & & & & \\
\hline Catering & & & & & \\
\hline Tourism information & & & & & \\
\hline $\begin{array}{l}\text { Operations of tourist } \\
\text { guides }\end{array}$ & & & & & \\
\hline $\begin{array}{l}\text { Service in tourism } \\
\text { attractions }\end{array}$ & & & & & \\
\hline $\begin{array}{l}\text { General assessment } \\
\text { (place) }\end{array}$ & & & & & \\
\hline
\end{tabular}

Source: Own elaboration 


\section{LIST OF REFERENCES}

1. Golembski G.: Turystyka jako czynnik integrujący badania naukowe. in: Kierunki rozwoju badań naukowych w turystyce, ed. G. Gołembski, Akademia Ekonomiczna w Poznaniu, Wydawnictwo Naukowe PWN, Warszawa 2003.

2. Gospodarka turystyczna, ed. A. Panasiuk, Wydawnictwo Naukowe PWN, Warszawa 2008, p. 44

3. Kompendium wiedzy o konkurencyjności, ed. M. Gorynia, E. Łaźniewska, Wydawnictwo Naukowe PWN, Warszawa 2009.

4. Kosikowski C., Lawicki T.: Ochrona prawna konkurencji i zwalczania praktyk monopolistycznych. PWN, Warszawa 1994.

5. Middeleton V.T.C.: Marketing w turystyce. PAPT, Warszawa 1996.

6. Freyer $W$., Tourismus, Einführung in die Fremdenverkhersőkonomie, R. Oldenburger Verlag, München 1991.

7. Page S., Hall C., Managing Urban Tourism, Prentice Hall, London 2002.

8. Panasiuk A.: Produkt turystyczny. Zeszyty Naukowe "Oeconomicus". Wyższa Szkoła Zawodowa "Oeconomicus", Szczecin 2001.

9. Pawlicz A., Promocja produktu turystycznego. Turystyka miejska, Difin, Warszawa 2008.

10. Regionalne aspekty rozwoju turystyki. Ed. G. Gołembski, Wydawnictwo Naukowe PWN, Warszawa - Poznań 1999.

11. Rosa G.: Marketing jako sposób wzmacniania pozycji konkurencyjne na rynku usług transportowych. Wydawnictwo Naukowe Uniwersytetu Szczecińskiego, Szczecin 2002.

12. Sztucki T.: Marketing przedsiębiorcy i menedżera. Agencja Wydawnicza Placet, Warszawa 1996.

13. Wodejko S.: Ekonomiczne zagadnienia turystyki. PWSH, Warszawa 1997.

14. Zawistowska $H .:$ Rola Unii Europejskiej w poprawie jakości produktów turystycznych. in: Kierunki rozwoju badań naukowych w turystyce, ed. G. Gołembski, Akademia Ekonomiczna w Poznaniu, Wydawnictwo Naukowe PWN, Warszawa 2003.

Стаття: надійшла до редколегї 02.06.2012

прийнята до друку 12.06.2012 


\title{
ЧИННИКИ КОНКУРЕНТОСПРОМОЖНОСТІ МІСЬКОГО ТУРИСТИЧНОГО ПРОДУКТУ
}

\author{
А. Панасюк \\ Університет Щеціна. Щеиин, Польща
}

Тенденції на ринку туризму, особливо елементи ринку, як глобалізація, лібералізація, криза в економіці, зміни в перевагах покупки, сила осіб пропонують туристичні продукти до пошуку нових рішень, які дозволять отримати конкурентну перевагу.

Туристичний продукт є багатовимірною категорією і включає в себе роботу туристичних осіб, що пропонують послуги. Тому туристичний продукт визначається роботою багатьох осіб, які керують елементами структури туристичного ринку.

Ключові слова: конкуренти, туристичний продукт, місто.

\section{ФАКТОРЫ КОНКУРЕНТОСПОСОБНОСТИ ГОРОДСКОГО ТУРИСТИЧЕСКОГО ПРОДУКТА}

\author{
А. Панасюк \\ Университет Щещина. Щещин, Польша
}

Тенденции на рынке туризма, особенно элементы рынка, как глобализация, либерализация, кризис в экономике, изменения в предпочтениях покупки, сила лиц предлагают туристические продукты к поиску новых решений, которые позволят получить конкурентное преимущество.

Туристический продукт является многомерной категорией и включает в себя работу туристических лиц, предлагающих услуги. Поэтому туристический продукт определяется работой многих лиц, которые управляют элементами структуры туристического рынка.

Ключевые слова: конкуренты, туристический продукт, город. 